\title{
Aparat Pengawas Intern Pemerintah: Perannya dalam Pengawasan Intelijen yang Akuntabel di Badan Intelijen Negara
}

\section{Wahyu Kuncoro}

\author{
Sekolah Tinggi Intelijen Negara, Bogor
}

\section{INTISARI}

Artikel ini hendak mengkaji praktik pengawasan intelijen yang dilaksanakan di Badan Intelijen Negara. Secara spesifik, tulisan ini berfokus pada bagaimana auditor internal dalam hal ini Aparat Pengawas Intern Pemerintah (APIP) berperan sebagai aparat pengawasan intelijen. Kajian ini menggunakan pendekatan kualitatif dengan metode deskriptif-analitis dengan melakukan penelaahan terhadap konsep-konsep dan teori-teori serta peraturan perundang-undangan yang ada. Metode pengumpulan data dilakukan melalui observasi lapangan, dan studi literatur primer serta sekunder. Hasil yang diperoleh adalah pelaksanaan pengawasan internal di Badan Intelijen Negara telah berjalan beriringan dengan pengawasan intelijen, dan didukung dengan berbagai kebijakan yang memadai. Pengawas internal telah menjalankan peran ganda baik sebagai pengawas internal dalam kerangka tata kelola pemerintahan yang baik sekaligus dalam perannya sebagai pengawas intelijen. Oleh karena itu, auditor internal di Badan Intelijen Negara memiliki peran yang strategis dalam menjalankan fungsi pengawasan internal sekaligus pengawasan intelijen. Meskipun demikian, terdapat beberapa hal yang perlu menjadi perhatian guna meningkatkan efektifitas dan akuntabilitas pengawasan intelijen, yaitu dibutuhkannya penyusunan kebijakan strategis nasional terkait pelaksanaan pengawasan intelijen, penyusunan metode pengawasan intelijen yang ilmiah, dan adanya ruang bagi partisipasi publik.

\section{KATA KUNCI}

APIP; intelijen; pengawasan internal; pengawasan intelijen; akuntabilitas; Badan Intelijen Negara

\section{Korespodensi:}

Program Studi Magister Kajian Intelijen Negara, Sekolah Tinggi Intelijen Negara, Sumur Batu, Babakan Madang, Sumur Batu, Bogor, Jawa Barat 16810.

Email: wahyukuncorowijaya@gmail.com 


\section{Pendahuluan}

$\mathrm{D}$ i sebagian besar negara-negara transisi, tujuan adanya demokratisasi intelijen adalah untuk melemahkan struktur pemerintahan otoriter dengan memperkenalkan ide-ide tentang transparansi, legalitas, dan pengawasan (Lurås, 2014). Artinya, pengawasan intelijen merupakan bagian penting dari ikhtiar untuk menjalankan demokratisasi di sektor intelijen. Pengawasan ini sendiri adalah usaha untuk memastikan bahwa dinas intelijen beroperasi dan melaksanakan tugastugas yang diamanatkan sesuai dengan batasan hukum nasional dan internasional. Dengan adanya pengawasan intelijen, maka secara tidak langsung telah berkontribusi dalam mempromosikan stabilitas jangka panjang dan pemerintahan demokratis yang berkelanjutan (Wegge, 2017).

Intelijen merupakan lembaga negara yang memiliki peran penting sekaligus kewenangan yang besar. Catatan sejarah di banyak negara menunjukkan bahwa intelijen seringkali digunakan untuk kepentingan politik penguasa suatu negara dan tidak jarang memiliki catatan kasus pelanggaran Hak Asasi Manusia (HAM). Di titik inilah pentingnya melakukan pengawasan intelijen secara demokratis. Sebab, hal ini memainkan peranan penting untuk memperkuat perlindungan hak asasi manusia dengan cara mengaudit kebijakan, meninjau operasi lembaga, dan dengan kerjasama intelijen internasional (Leigh, 2012).

Tidak terkecuali dengan Indonesia, banyak kalangan menyoroti kerja dinas intelijen yang perlu diaudit, terutama agar operasi kerjanya tidak menabrak koridor HAM. Untuk itu, muncullah tuntutan-tuntutan agar dilakukan reformasi sektor intelijen, dengan salah satu perwujudannya adalah disahkannya Undang-Undang Republik Indonesia Nomor 17 Tahun 2011 tentang Intelijen Negara atau biasa disingkat sebagai UU Intelijen. Dengan UU Intelijen ini, maka kepastian hukum bagi pelaksanaan aktivitas intelijen, sekaligus batasan atas peran dan kewenangan Intelijen menjadi jauh lebih pasti. Dalam UU Intelijen misalnya, diatur antara lain mengenai peran, tujuan, fungsi, ruang lingkup, penyelenggaraan, kerahasiaan, koordinasi, pembiayaan, pertangungjawaban, pengawasan Intelijen, dan juga terkait ketentuan pidana. Intelijen tidak bisa lagi bekerja sesuai kemauan atau otonominya sendiri, namun harus tunduk pada perintah undang-undang.

Sejarah Intelijen di Indonesia menunjukkan bahwa intelijen pernah dipolitisasi dan digunakan untuk tujuan-tujuan atau kepentingan politik tertentu. Selain itu, operasi intelijen juga tidak hanya sekali melakukan penyimpangan dan institusi intelijen dituduh berada di balik sejumlah pelanggaran HAM. Sejumlah kasus pelanggaran HAM diduga melibatkan operasi intelijen misalnya saja operasi militer di Aceh, Timor-Timur, Papua, Peristiwa Malapetaka 15 Januari 1974 (Malari), peristiwa Tanjung Priok 1984, kasus Talangsari di Lampung, kasus penembakan misterius (petrus) di era 1980an, dan terakhir adalah kasus penghilangan aktivis sepanjang tahun 1997-1998 (Bhakti, Mengko, Samego, Yanuarti, \& Siregar, 2016). Selain itu, institusi intelijen juga pernah menjadi lembaga yang diperebutkan oleh berbagai aktor politik seperti pernah terjadi pada era Soekarno (Samego, 2017).

Untuk menjamin Intelijen tidak melakukan penyimpangan dan pelanggaran HAM, maka pengawasan intelijen mutlak diperlukan. Yanuarti (2017a, 2017b) menyebut setidaknya ada lima alasan mengapa pengawasan intelijen penting untuk dilakukan. Pertama, intelijen berkerja hampir selalu secara rahasia dimana hal tersebut bertentangan dengan konsep pengawasan demokratis yang 
menekankan pada keterbukaan dan transparansi. Kedua, intelijen memiliki kapasitas dan kapabilitas khusus seperti memasuki wilayah pribadi atau komunikasi yang bersinggungan dengan prinsip HAM, sehingga membutuhkan pengawasan yang ketat. Ketiga, terjadinya penyesuaian intelijen sebagai konsekuensi dari adanya bentuk ancaman keamanan baru sehingga membutuhkan pengawasan yang tepat. Keempat, intelijen memiliki fungsi sebagai pengumpul dan penganalisis informasi mengenai kemungkinan adanya ancaman serta membuat penilaian atas adanya ancaman. Penilaian atas ancaman ini merupakan kewenangan yang menjadi titik awal kemungkinan terjadinya penyimpangan oleh intelijen negara. Kelima, pengawasan intelijen secara demokratik menjadi suatu keharusan karena institusi intelijen pada masa lalu (rezim otoriter) seringkali digunakan untuk melindungi kekuasaan pemimpin otoriter dan menjadi alat represif.

Penyelenggaraan pengawasan intelijen dilakukan dengan mengiplementasikan pengawasan berlapis (multilayered oversight) yang bertujuan untuk menjamin dan meningkatkan akuntabilitas politik, hukum, dan keuangan. Pengawasan berlapis ini menempatkan intelijen pada bagian tengah, dan dikelilingi oleh lapis-lapis pengawasan, dimana pengawasan pada satu lapisan juga menjadi cakupan bagi pengawasan pada lapis berikutnya. Lapis-lapis pengawasan ini diselenggarakan melalui pengawasan internal, pengawasan eksekutif, pengawasan parlemen, dan pengawasan publik (Drohan, 2010; Widjajanto \& Wardhani, 2008).

Pengawasan intelijen secara berlapis ini sebenarnya telah diatur di dalam UU Intelijen, tetapi hanya disebutkan adanya dua lapis pengawasan. Hal tersebut dapat dilihat pada Pasal 43 UU Intelijen yang mengatur mengenai adanya pengawasan intelijen secara internal dan eksternal, dimana disebutkan bahwa pengawasan internal untuk setiap penyelenggara Intelijen Negara dilakukan oleh pimpinan masing-masing. Sedangkan pengawasan intelijen eksternal dilaksanakan oleh DPR melalui komisi yang membidangi masalah intelijen. DPR sendiri telah mengeluarkan Peraturan DPR Nomor 2 Tahun 2014 tentang Tim Pengawasan Intelijen.

Dalam banyak kasus di dunia, pengawasan melalui parlemen (DPR) sebenarnya adalah cara yang sangat efektif untuk mengontrol kerja dinas intelijen menjadi lebih akuntabel, karena parlemen bekerja dengan mengatas-namakan kepentingan publik (Jackson Jr., 1990; Karalekas, 1983; Zegart \& Quinn, 2010). Sayangnya, dalam kasus di Indonesia, pengawasan intelijen oleh DPR hanya bersifat ad-hoc, dan baru akan bekerja apabila terjadi penyimpangan dalam pelaksanaan fungsi intelijen. Sementara pengawasan oleh eksekutif dan yudikatif maupun pengawasan publik belum diatur secara tegas di dalam UU Intelijen. Pada titik ini, Indonesia seharusnya bisa belajar dari kegagalan Ghana dalam melakukan reformasi di sektor intelijen. Kegagalan itu terjadi karena kelemahan yang melekat dalam mekanisme kelembagaan, serta kurangnya kemauan politik (political will) dan lemahnya penegakan prinsip-prinsip konstitusi dan hukum (Obuobi, 2018).

Ini berarti, tidak adanya klausul pengawasan oleh publik adalah titik lemah tersendiri bagi UU intelijen. Padahal, dalam banyak kasus di dunia, keterlibatan publik melalui media massa (cetak maupun elektronik) misalnya, dalam pengawasan intelijen ternyata mempunyai peran yang signifikan. Setidaknya ada tiga peran terpenting, yakni sebagai pemancar informasi dan stimulator bagi pengamat formal, sebagai pengawas pengganti dan sebagai pengawas legitimasi lembaga (Hillebrand, 2012). 
Contoh sukses semacam itu adalah reformasi intelijen di Perancis, yang berhasil membangun sistem akuntabilitas intelijen dengan memanfaatkan hubungan yang lebih kolaboratif antara lembagalembaga pemerintah dan media (Puyvelde, 2014).

Terlepas dari penilaian masih adanya kelemahan dalam mekanisme pengawasan eksternal, penulis melihat adanya peran strategis yang dijalankan oleh Aparat Pengawas Internal Pemerintah (APIP) dalam pelaksanaan pengawasan intelijen di Badan Intelijen Negara (BIN). APIP adalah instansi pemerintah yang dibentuk dengan tugas melaksanakan pengawasan intern di lingkungan pemerintah. APIP di BIN sendiri adalah Inspektorat Utama, yaitu unsur pengawasan di lingkungan BIN yang berada di bawah dan bertanggung jawab kepada Kepala BIN sesuai dengan Pasal 32 ayat (1) pada Peraturan Presiden Nomor 73 Tahun 2017 tentang Perubahan atas Peraturan Presiden Nomor 90 Tahun 2012 tentang Badan Intelijen Negara.

Berangkat dari latar belakan di atas, maka tulisan ini mengambil posisi sebagai analisis dari perspektif pengawas internal dalam kerja Badan Intelijen Negara. Inilah gap analisis yang hendak diisi oleh tulisan ini, yakni mencoba memaparkan bagaimana paradigma pengawasan internal dapat berjalan bersama dengan paradigma pengawasan intelijen. Di samping itu, tulisan ini juga ingin mengungkap peran apa saja yang dapat dilakukan APIP dalam pelaksanaan pengawasan intelijen di Badan Intelijen Negara. Kajian ini menggunakan pendekatan kualitatif dengan metode deskriptifanalitis dengan melakukan penelaahan terhadap konsep-konsep dan teori-teori serta peraturan perundang-undangan yang ada. Metode pengumpulan data dilakukan melalui observasi lapangan, dan studi literatur primer serta sekunder. Data-data yang diperoleh dari literatur disandingkan dengan observasi lapangan guna memperoleh data yang akurat. Berbagai temuan yang diperoleh dianalisis dan ditelaah dengan literatur lain guna mendapat kesimpulan penelitian yang sesuai.

\section{APIP: Peran dan Koridor yang Melingkupinya}

Dalam Kerangka Konseptual Pengawasan Intern Pemerintah Indonesia, APIP berkewajiban melaksanakan pengawasan intern, yaitu seluruh proses kegiatan audit, review, pemantauan, evaluasi dan kegiatan pengawasan lainnya terhadap penyelenggaraan tugas dan fungsi organisasi dalam rangka memberikan keyakinan yang memadai bahwa kegiatan telah dilaksanakan sesuai dengan tolok ukur yang ditetapkan bahwa secara operasional telah dilaksanakan efektif dan efisien untuk kepentingan pimpinan mewujudkan tata kelola pemerintahan yang baik. Sebagai pengawas intern, APIP memiliki peran sebagai auditor intern dan memberikan keyakinan yang memadai atas ketaatan, kehematan, efisiensi, dan efektivitas pencapaian tujuan penyelenggaraan tugas dan fungsi Instansi Pemerintah, memberikan peringatan dini dan meningkatkan efektivitas manajemen risiko dalam penyelenggaraan tugas dan fungsi Instansi Pemerintah, dan memelihara dan meningkatkan kualitas tata kelola penyelenggaraan tugas dan fungsi Instansi Pemerintah (Pasal 11, Peraturan Pemerintah Republik Indonesia Nomor 60 Tahun 2008 tentang Sistem Pengendalian Intern Pemerintah).

Peran APIP BIN, selain untuk memberikan transparansi dan akuntabilitas yang merupakan salah satu ukuran good governance juga berkewajiban melaksanakan pengawasan intelijen. Hal ini diamanatkan UU Intelijen Pasal 43, yang menyebutkan bahwa pengawasan internal untuk setiap 
penyelenggara Intelijen Negara dilakukan oleh pimpinan masing-masing. Pada Pasal 32 ayat (1) Perpres Nomor 90 Tahun 2012 sebagaimana diubah dengan Perpres 73 Tahun 2018 tentang Badan Intelijen Negara menyebut bahwa unsur pengawasan di lingkungan BIN yang berada di bawah dan bertanggung jawab kepada Kepala BIN adalah Inspektorat Utama. Hal ini berarti APIP di BIN, dalam hal ini Inspektorat Utama BIN, disamping sebagai pelaksana pengawasan atas tata kelola pemerintahan secara umum, juga memiliki peran dalam pelaksanaan pengawasan intelijen.

Aktivitas intelijen membutuhkan pengawasan dan pertanggungjawaban untuk menjamin suatu operasi yang dilakukan oleh tidak melanggar hukum dan dilandasi oleh prinsip penegakan hukum, menghormati hak asasi manusia, dan absah (legitimate) di mata publik (Born \& Leigh, 2007: 12). Namun, intelijen juga memerlukan sifat dan prinsip kerahasiaan untuk menjaga efektivitas operasinya. Oleh karena itu, pengawasan intelijen yang dilakukan harus memperhatikan aspek pertanggungjawaban yang akuntabel sekaligus juga tetap memberikan jaminan atas kerahasiaan intelijen.

Dengan karakteristik intelijen yang rahasia, APIP sebagai pengawas intelijen yang ada di intern BIN, memiliki peranan yang sangat penting dan strategis. APIP sebagai pengawas intelijen intern juga merupakan personel intelijen negara yang terikat dengan sumpah intelijen dan kode etik intelijen, sehingga dapat melakukan pengawasan intelijen yang efektif tanpa khawatir terjadi kebocoran intelijen. Pengawasan Intelijen secara internal juga efektif dalam melihat apakah suatu aktivitas intelijen berjalan pada koridor hukum dan penghormatan terhadap HAM karena memiliki akses terhadap operasi intelijen secara beriringan. Pengawasan intelijen internal juga dapat memberikan suatu early warning terhadap aktivitas intelijen yang dijalankan sehingga dapat menghindarkan intelijen dari kesalahan operasi.

Pengawasan intelijen tentu harus memperhatikan aspek-aspek penting yang menjadi karakteristik khas intelijen. Intelijen sebagai suatu entitas dengan berbagai kewenangan dan kemampuan khusus yang dimiliki, mutlak memerlukan pengawasan dengan kemampuan dan metode khusus pula. Terdapat tiga aspek utama dalam praktik pengawasan intelijen di BIN, yaitu pada aspek program kerja dan kinerja intelijen, aspek personel intelijen, serta aspek keuangan dan logistik intelijen. Ketiga aspek tersebut memerlukan pengawasan dengan pendekatan yang berbeda meskipun tetap dalam pelaksanaannya saling terkait dan tidak dapat dipisahkan. Penekanan terhadap tiga aspek utama pengawasan intelijen tersebut dinilai sebagai praktik terbaik yang diterapkan di BIN sehingga pengawasan intelijen dapat dilakukan secara efektif dan efisien.

Dalam pelaksanaan pengawasan intelijen, terdapat beberapa tantangan APIP dalam mewujudkan pengawasan intelijen yang akuntabel antara lain, pertama, belum ada definisi yang baku mengenai pengawasan intelijen. UU Intelijen tidak menyebutkan secara rinci asas, aspek, dan metode dalam pelaksanaan pengawasan intelijen. Ketiadaan definisi ini mengakibatkan pelaksanaan pengawasaan intelijen sangat mungkin berbeda antara satu penyelenggara intelijen negara dengan penyelenggara intelijen lainnya. Terlebih lagi pengawasan intelijen secara internal diserahkan kepada pimpinan masing-masing penyelenggara intelijen. Pada sisi yang lain, BIN sebenarnya memiliki kewenangan untuk menyusun rencana dan kebijakan nasional di bidang Intelijen secara menyeluruh (Pasal 30 
huruf a UU Intelijen). Kewenangan ini semestinya dapat digunakan selain untuk menyusun rencana strategis intelijen secara nasional, juga termasuk bagaimana kerangka pengawasan intelijen terhadap penyelenggaraan intelijen.

Kedua, dalam penyelenggaraan intelijen berlaku asas kompartementasi. Dalam penjelasan UU Intelijen dinyebutkan bahwa yang dimaksud dengan "asas kompartementasi" adalah dalam menjalani tugas dan fungsinya, aktivitas Intelijen terpisah satu sama lain, dan hanya diketahui oleh unit yang bersangkutan. Hal ini berarti bahwa dalam pelaksanaan operasi intelijen, unit operasional intelijen bekerja secara tertutup terhadap unit lain, termasuk terhadap pengawas intelijen. Meskipun pada prinsipnya tidak ada kerahasiaan bagi pengawas, tetapi dengan asas kompartementasi intelijen maka pengawasan terhadap aktivitas tertentu hanya dapat dilaksanakan secara post-audit. Pengawasan secara post-audit berarti bahwa pengawasan dilakukan setelah kegiatan atau aktivitas intelijen yang dijalankan telah selesai.

Konsekuensi dari post-audit ini adalah bahwa operasi intelijen masih menyimpan potensi penyimpangan dalam pelaksanaannya. Hal ini sebenarnya dapat disiasati dengan dua cara, pertama, pengawasan intelijen dilaksanakan secara melekat dalam operasi intelijen, atau kedua, perencanaan operasi melibatkan unsur pengawas intelijen sehingga desain operasi yang hendak dilaksanakan dapat diyakini tidak akan menyimpang. Hal ini sesuai dengan tuntutan peran APIP sebagai assurance dan consulting dalam rangka memberikan keyakinan yang memadai bahwa kegiatan telah dilaksanakan sesuai dengan tolok ukur yang ditetapkan.

Ketiga, belum ada metode dan teknik pengawasan yang secara khusus ditujukan bagi kepentingan pengawasan intelijen. Ketiadaan metode dan teknik dalam pengawasan intelijen ini menjadikan para pengawas intelijen harus mampu mengembangkan metode dan tekniknya sendiri untuk menghadapi berbagai situasi pengawasan yang terjadi. Sehingga, pengawasan intelijen masih tergantung pada pengalaman, kapabilitas dan kreatifitas para pengawas intelijen.

Keempat, oleh karena itu, tantangan utama dalam pelaksanaan pengawasan intelijen adalah peningkatan kualitas Sumber Daya Manusia (SDM) pengawas intelijen. SDM selain dari sisi kuantitas, yang lebih penting adalah aspek kualitas. Pengawasan intelijen memerlukan pemahaman yang luas dan mendalam tidak saja tentang penyelenggaraan intelijen dengan kewenangan dan berbagai metode, teknik, dan taktiknya, tetapi juga memerlukan pemahaman pada aspek penghormatan atas HAM dan hukum yang berlaku.

Dari sisi penyelenggaraan intelijen, perkembangan ancaman menjadi lebih beragam dan tersebar ikut membuat organisasi intelijen dituntut dapat menyesuaikan diri dengan dinamika yang terjadi. Bergesernya doktrin ancaman dari sebelumnya bersifat militer, bergeser menjadi ancaman nonmiliter. Ancaman non militer ini meliputi ideologi, politik, ekonomi, sosial dan budaya. Hal ini dapat dilihat dari definisi ancaman dalam UU Intelijen, yaitu setiap upaya, pekerjaan, kegiatan, dan tindakan, baik dari dalam negeri maupun luar negeri, yang dinilai dan/atau dibuktikan dapat membahayakan keselamatan bangsa, keamanan, kedaulatan, keutuhan wilayah Negara Kesatuan Republik Indonesia, dan kepentingan nasional di berbagai aspek, baik ideologi, politik, ekonomi, 
sosial budaya, maupun pertahanan dan keamanan. Sayangnya, belum ada perincian terhadap batasan apa yang dinilai membahayakan.

Dalam konteks tersebut, pengawasan intelijen harus cermat dalam menilai apakah aktivitas intelijen telah digunakan untuk meminimalisasi bahaya dan ancaman yang muncul. APIP sebagai pengawas intelijen harus mampu memberikan argumen-argumen dasar terhadap apa yang dapat dinilai membahakan atau tidak. Kesalahan dalam penilaian tersebut, dapat membuat rekomendasi pengawasan intelijen menjadi tidak tepat yang dapat membuat pelaksanaan operasi intelijen menjadi tidak efektif, bahkan gagal dalam mendeteksi dan menangkal ancaman.

Tantangan lain adalah potensi kebocoran informasi melalui teknologi informasi, baik secara sengaja maupun tidak. Pembocoran intelijen secara sengaja yang paling menggemparkan komunitas intelijen hingga saat ini adalah kasus Edward Snowden. Sebagian orang menyebutnya whistle blower dan pahlawan, tetapi sebagian lainnya menganggapnya pengkhianat karena telah membocorkan rahasia intelijen. Snowden membocorkan berbagai rahasia CIA dan NSA sebagai bentuk protes dan ketidaksetujuannya terhadap tindakan pemerintah (Djoyonegoro, 2018: 106). Sementara di Indonesia sediri, sempat terjadi beberapa kebocoran atas Surat Edaran internal di BIN dan muncul di beberapa media sosial.

Pada era siber ini, sangat rentan terjadi pembocoran intelijen, sehingga diperlukan langkahlangkah pengamanan, baik dari sisi infrastruktur jaringan, dan terutama manusianya itu sendiri. Adanya kekecewaan-kekecewaan yang dirasakan personel intelijen tentu merupakan suatu tantangan jika bukan ancaman bagi kepentingan intelijen. Pengawasan intelijen selain memastikan bahwa penyelenggaraan intelijen berjalan pada koridor hukum dan penghormatan atas HAM, juga harus mampu mewadahi dan mengarahkan berbagai potensi ketidakpuasan personel intelijen. Dengan kata lain, pengawasan intelijen juga harus mencakup pada pengelolaan permasalahan internal sehingga dapat diselesaikan secara baik dan tidak berkembang menjadi potensi ancaman bagi intelijen itu sendiri.

\section{Mod'el Pengawasan Berlapis Bagi Intelijen}

Pengawasan intelijen di Indonesia pada dasarnya mengadopsi model pengawasan berlapis (multilayer oversight) dimana pengawasan intelijen dilaksanakan beberapa lapisan pengawasan. Idealnya, pengawasan berlapis ini dilaksanakan setidaknya oleh empat lapisan, pertama, pengawasan internal yang dilakukan oleh pimpinan masing-masing lembaga intelijen sebagaimana praktik pengawasan birokrasi pemerintahan. Kedua, pengawasan oleh eksekutif yang dilaksanakan oleh presiden terhadap badan intelijen yang ada di bawahnya, atau kementerian/lembaga yang menangani pengawasan internal pemerintah. Ketiga, pengawasan oleh lembaga legislatif. Dan keempat, pada lapisan paling luar, dilaksanakan oleh badan independen dan kelompok masyarakat sipil. Namun, UU Intelijen tidak secara tegas menyebutkan pelaksanaan pengawasan intelijen dilakukan oleh keempat lapis pengawasan tersebut, kecuali bahwa pengawasan intelijen dilaksanakan oleh secara internal oleh pimpinan masing-masing dan eksternal oleh DPR RI. 
Pengawasan intelijen ini masih menjadi permasalahan tersendiri, dimana sebagian kalangan belum cukup puas dengan pengaturannya di dalam UU Intelijen. Pengawasan Intelijen oleh Tim Pengawasan Intelijen Negara di DPR-RI memiliki keterbatasan dimana tidak memiliki kewenangan untuk secara aktif melakukan pengawasan, dan juga mengubah atau menganulir suatu kebijakan serta operasi yang dilakukan oleh institusi intelijen negara (Bhakti dkk., 2016). Keterbatasan tersebut terjadi akibat peran, fungsi dan tugas Tim Pengawas Intelijen Negara di DPR-RI hanya bersifat adhoc. Pengawasan dapat dilakukan oleh DPR pada saat penyelenggara intelijen negara diduga atau dinilai telah melakukan penyimpangan. Di sisi lain, UU Intelijen juga tidak merinci dan memberikan indikator atas terjadinya penyimpangan. Kedua, Tim Pengawas Intelijen Negara di DPR-RI tidak berwenang melakukan pengawasan atas penggunaan anggaran institusi penyelenggara intelijen negara. UU Intelijen maupun Peraturan DPR Nomor 2 Tahun 2014 tentang Tim Pengawas Intelijen Negara di Dewan Perwakilan Rakyat Republik Indonesia, tidak menyebutkan mengenai mekanisme pengawasan terhadap anggaran penyelenggara intelijen negara. Disamping itu, wewenang terkait investigasai dan akses terhadap informasi tidak dijabarkan secara terperinci sampai pada batasan mana dapat dilakukan oleh Tim Pengawas Intelijen Negara di DPR-RI.

Di dalam UU Intelijen, hanya diatur mengenai pengawasan intelijen eksternal yang dilaksanakan oleh DPR. Sementara, pengawasan oleh eksekutif dan yudikatif belum diatur. Sedangkan untuk pengawasan intern, hanya disebutkan bahwa pengawasan internal untuk setiap penyelenggara Intelijen Negara dilakukan oleh pimpinan masing-masing. Meskipun demikian, penulis menemukan bahwa secara faktual pengawasan terhadap penyelenggara intelijen sebenarnya telah dilakukan baik oleh internal, eksekutif, legislatif, maupun masyarakat sipil.

Pengawasan intelijen di BIN, selain dilaksanakan oleh APIP dan DPR RI, juga dilaksanakan oleh eksekutif, dimana BIN harus mempertanggungjawabkan kinerjanya kepada Presiden, baik secara langsung maupun melalui pengawasan dan evaluasi dari Kementerian/Lembaga lain. Pengawasan dan evaluasi terhadap BIN juga dilakukan oleh antara lain Kementerian Pendayagunaan Aparatur Negara dan Reformasi Birokrasi (Kemen-PANRB), Kementerian Keuangan, Badan Pengawasan Keuangan dan Pembangunan (BPKP), Komisi Aparatur Sipil Negara (KASN), dan lembaga-lembaga lain sesuai peraturan perundang-undangan. Selain itu, setiap tahun Badan Pengawas Keuangan (BPK) sebagai lembaga independen juga melakukan Audit terhadap Laporan Keuangan BIN. BIN sendiri telah mendapatkan opini Wajar Tanpa Pengecualian (WTP) sebanyak 12 kali berturut-turut dari BPK. Opini WTP sendiri adalah opini tertinggi yang diberikan oleh BPK atas audit yang dilakukan terhadap Laporan Keuangan. Sedangkan hasil evaluasi terhadap pelaksanaan Reformasi Birokrasi di BIN oleh Kemen PANRB telah menunjukkan hasil yang baik dengan Indeks Reformasi Birokrasi BIN saat ini 75,90 dan telah melampaui target yang ditetapkan Pemerintah dalam Rencana Pemerintah Jangka Menengah Nasional sebesar 75,00.

Pengawasan-pengawasan yang dilakukan berbagai lembaga tersebut memang tidak secara spesifik melaksanakan pengawasan atas penyelenggaraan intelijen. Namun setidaknya, hal tersebut menggambarkan bahwa sesungguhnya BIN sebagai penyelenggara intelijen tidaklah bebas dari 
pengawasan, tetapi tunduk terhadap pengawasan lembaga lain sesuai dengan ketentuan perundangundangan.

Selain pelaksanaan pengawasan oleh unsur eksternal, Kepala BIN juga telah menetapkan beberapa peraturan mengenai antara lain penanganan benturan kepentingan, pengendalian gratifikasi, penanganan pengaduan masyarakat, dan penanganan pengaduan tindak pidana korupsi (whistle blowing system) di lingkungan Badan Intelijen Negara. Berbagai peraturan dan kebijakan tersebut dalam rangka mendukung pelaksanaan pengawasan intelijen internal yang efektif dan efisien sekaligus akuntabel. Berbagai instrumen tersebut diharapkan ikut mendorong pastisipasi publik, terutama yang berasal dari internal lembaga intelijen, dalam pengawasan terhadap penyimpangan yang mungkin terjadi.

Selain itu, menghadapi tuntutan APIP selaku pengawas intelijen, Kepala BIN juga telah menetapkan peraturan tentang kebijakan pengawasan intelijen di lingkungan BIN, yang digunakan sebagai dasar dari pelaksanaan pengawasan intelijen di BIN. Peraturan tersebut memberikan panduan pelaksanaan pengawasan intelijen, yang meliputi kebijakan dan strategi pengawasan, tujuan pengawasan, kegiatan pengawasan, dan objek pengawasan. Secara umum, pelaksanaan pengawasan intelijen telah didukung dengan berbagai peraturan yang memadai, sehingga pengawasan intelijen di BIN dapat dipertanggungjawabkan kualitasnya.

\section{Strategi Penguatan Peran APIP dalam Pengawasan Intelijen}

Besarnya peran APIP BIN dalam pelaksanaan pengawasan intelijen, selain dengan menetapkan berbagai peraturan dan kebijakan terkait pengawasan intelijen, diperlukan suatu strategi penguatan peran APIP untuk meningkatkan akuntabilitas pengawasan intelijen. Salah satu strategi yang diterapkan oleh BIN saat ini adalah dengan meningkatkan kualitas Sumber Daya Manusia (SDM) APIP sebagai pelaksana pengawasan intelijen di Internal BIN. Hal ini didasari oleh pemikiran bahwa BIN memiliki sifat khas yakni rahasia, sehingga pelaksanaan pengawasan akan mengandung paradoks ketika dikaitkan dengan adanya kontrol sebagaimana yang biasa dianut dalam sistem negara demokrasi. Oleh karena itu, Pengawasan internal di BIN memiliki area khusus yang tidak dimiliki APIP di Kementerian/Lembaga pada umumnya, terlebih APIP di BIN juga dituntut untuk tetap mengedepankan rahasia intelijen (Pusat Pembinaan Profesi, 2018: 6). Selain itu, peran yang diemban oleh APIP BIN memiliki dua dimensi pengawasan, yaitu pertama, pengawasan terhadap tata kelola pemerintahan sebagaimana diatur dalam berbagai peraturan perundang-undangan yang berlaku umum bagi seluruh APIP di Indonesia. Dan kedua, pengawasan terhadap penyelenggaraan intelijen sebagaimana amanat UU Intelijen.

Dengan ditetapkannya berbagai peraturan dan kebijakan pengawasan intelijen, APIP BIN secara resmi telah mengemban dua peran pengawasan sekaligus. Pertama, selaku pengawas intern yang tunduk pada ketentuan perundang-undangan dan berbagai ketetapan APIP selaku asosiasi profesi auditor internal. Pada perannya sebagai auditor internal, APIP BIN melaksanakan pengawasan internal berupa kegiatan audit, reviu, pemantauan, evaluasi dan kegiatan pengawas lainnya untuk mewujudkan tata kelola pemerintahan yang baik. Perannya yang kedua, adalah melaksanakan pengawasan intelijen 
yang dilakukan guna memenuhi tuntutan terkait dengan pencegahan pelanggaran HAM. Pengawasan intelijen internal juga dituntut memberikan nilai tambah dan meningkatkan efektifitas pelaksanaan intelijen dalam rangka pencegahan, penangkalan, dan penanggulangan terhadap setiap hakikat ancaman yang mungkin timbul dan mengancam kepentingan dan keamanan nasional.

Peningkatan kualitas SDM APIP ini dilaksanakan dengan merumuskan Jabatan Fungsional Pengawas Intelijen (JFPI) yang khusus menangani permasalah pengawasan intelijen. Perumusan JFPI ini merupakan jawaban atas tuntutan pengawasan intelijen secara internal yang akuntabel. Dengan adanya JFPI ini, setiap APIP BIN dituntut memiliki kemampuan ganda, yaitu pemahaman atas penyelenggaraan tata kelola pemerintahan yang baik (good governance), dan juga pemahaman atas prinsip-prinsip penyelenggaraan intelijen sesuai tuntutan reformasi sektor intelijen.

Penyusunan JFPI ini juga diharapkan memberikan dampak positif terhadap berbagai program pengembangan pengawasan intelijen di BIN, antara lain:

(1) Berkembangnya kompetensi teknis, manajerial, dan sosial kultural bagi pengawas intelijen secara jelas dan tepat sasaran; (2) Terselenggaranya pendidikan dan pelatihan yang sesuai tuntutan kompetensi pengawas intelijen di BIN; (3) Terwujudnya SDM yang profesional dalam pelaksanaan tugas dan fungsinya; (4) Meningkatnya kinerja BIN yang semakin efektif, efisien, dan ekonomis; serta (5) Berkembangnya pengawasan intelijen, baik dari sisi metode dan teknik maupun efektifitasnya, sehingga menghasilkan kualitas pengawasan yang akuntabel. (Pusat Pembinaan Profesi, 2018: 4)

Penyusunan jabatan fungsional ini menegaskan peran APIP BIN sebagai pengawas internal yang bertanggung jawab kepada Kepala BIN terkait pelaksanaan tugas pengawasan intelijen. Hal ini berarti bahwa Kepala BIN memiliki perhatian pada upaya peningkatan akuntabilitas kinerja BIN sekaligus memastikan penyelenggaraannya telah berjalan sesuai koridor yang ada. Setidaknya ada tiga ukuran keberhasilan dari penyelenggaraan pengawasan intelijen, yaitu adanya jaminan terhadap ketaatan kepada hukum (assurance of legality), proporsionalitas tindakan (proportionality) dan ukuran kepatutan (propriety) dalam melaksanakan aktivitas yang yang bersifat rahasia (Jemadu, 2007: 9). Ketiga ukuran keberhasilan tersebut secara umum telah terpenuhi dalam penyelenggaraan pengawasan intelijen di BIN. Hal tersebut dapat dilihat dari adanya pengaturan yang jelas atas pelaksanaan pengawasan intelijen, dan adanya kegiatan supervisi terhadap pelaksanaan operasi intelijen yang sedang dilakukan.

Terlepas dari segala upaya yang telah dilakukan dalam peningkatan efektifitas pengawasan intelijen di BIN, penulis memiliki beberapa catatan. Beberapa hal yang menjadi perhatian penulis antara lain pertama, belum adanya kebijakan strategis nasional terkait pelaksanaan pengawasan intelijen. Belum ada mekanisme pertanggungjawaban publik atas hasil kerja pengawasan intelijen oleh APIP BIN. Meskipun UU Intelijen tidak mengamanatkan bahwa hasil pengawasan intelijen secara internal perlu dipertanggunjawabkan secara publik, tetapi hal tersebut perlu dilakukan guna menjamin pengawasan internal berjalan sesuai tuntutan publik. Mekanisme pertanggungjawaban publik ini bisa saja dengan penyusunan ikhtisar laporan hasil pengawasan intelijen kepada Tim Pengawas Intelijen Negara di DPR-RI secara tahunan (Inspektorat Utama, 2019). 
Kedua, metode dan teknik pengawasan intelijen juga perlu dirumuskan secara jelas dan terbuka, sehingga publik dapat meyakini bahwa pengawasan intelijen yang dilakukan dapat menjawab kekhawatiran akan potensi penyimpangan intelijen. Berbagai kebijakan pengawasan intelijen di BIN belum dapat diuji oleh publik terkait keandalan metode pengawasannya. Metode atau model pengawasan intelijen harus dapat dipertanggungjawabkan secara ilmiah, logis, dan objektif. Publik, dalam hal ini sesama komunitas pengawas internal atau para pengkaji intelijen lain harus dapat menguji dan memberikan masukan bagi pengembangan model pengawasan intelijen yang efektif dan akuntabel.

Ketiga, pengawasan intelijen harus memberikan ruang yang luas bagi masyarakat untuk ikut mengawasi intelijen dengan memberikan sarana pengaduan dan pelaporan penyimpangan secara aman melalui sistem informasi. Mekanisme yang saat ini masih belum memberikan ruang yang cukup bagi masyarakat untuk ikut berpastisipasi dalam mengawasi intelijen.

\section{Kesimpulan}

Pelaksanaan pengawasan intelijen di Indonesia dilaksanakan baik secara internal maupun secara eksternal. Pelaksanaan secara eksternal dilaksanakan oleh DPR RI melalui Tim Pengawas Intelijen Negara di DPR-RI. Selain itu, pengawasan oleh eksekutif juga dilakukan meskipun tidak secara spesifik menggunakan terminologi pengawasan intelijen. Sedangkan pengawasan internal dilakukan oleh Aparat Pengawas Intern Pemerintah (APIP) yang mengemban peran ganda. APIP di BIN selain melaksanakan peran pengawasan dalam kerangka tata kelola pemerintahan yang baik, juga melaksanakan peran pengawasan intelijen sebagaimana tuntutan reformasi sektor intelijen.

Pengawasan intern dalam rangka tata kelola pemerintahan yang baik dilaksanakan dalam rangka memberikan keyakinan yang memadai bahwa kegiatan suatu unit organisasi telah dilaksanakan sesuai dengan tolok ukur yang ditetapkan, dan telah dilaksanakan secara efektif dan efisien. Sedangkan pengawasan intelijen dilaksanakan dalam kerangka untuk menjamin Intelijen tidak melakukan penyimpangan dan pelanggaran HAM sekaligus memberikan nilai tambah dan meningkatkan efektifitas pelaksanaan intelijen dalam rangka pencegahan, penangkalan, dan penanggulangan terhadap setiap hakikat ancaman yang mungkin timbul dan mengancam kepentingan dan keamanan nasional.

Dengan demikian, APIP di BIN memiliki peran strategis dalam melaksanakan fungsi pengawasan intelijen secara akuntabel. APIP di BIN juga melaksanakan pengawasan dengan dua paradigama sekaligus, yaitu paradigma penyelenggaraan tata kelola pemerintahan yang baik, sekaligus paradigma penyelenggaraan intelijen yang berjalan sesuai koridor hukum dan penghormatan atas HAM. Peran ganda APIP di BIN juga perlu ditopang dengan peningkatan kualitas Sumber Daya Manusia (SDM). SDM APIP di BIN harus memenuhi kompetensi sebagai auditor internal, sekaligus pengawas intelijen. Salah satu upaya peningkatan kualitas SDM APIP di BIN saat ini adalah dengan perumusan dan penyusunan Jabatan Fungsional Pengawas Intelijen.

Meskipun demikian, terdapat beberapa hal yang perlu dilakukan guna meningkatkan efektivitas dan akuntabilitas pengawasan intelijen. Pertama, Badan Intelijen Negara (BIN) perlu menyusun 
kebijakan strategis nasional terkait pelaksanaan pengawasan intelijen. Kedua, penyusunan dan penetapan metode dan teknik yang digunakan dalam pengawasan intelijen harus berdasarkan kajian ilmiah dan dilakukan peer review sehingga menghasilkan metode yang efektif sekaligus akuntabel. Dan ketiga, pengawasan intelijen internal perlu membuka ruang bagi partisipasi publik dengan didukung teknologi informasi sehingga dapat memberikan jaminan keamanan bagi para pelapor. Ketiga hal tersebut perlu dilakukan guna menjamin dan meningkatkan kualitas pengawasan intelijen atas penyelenggaraan intelijen.

\section{Ucapan Terima Kasih}

Terima kasih kepada STIN, dan secara khusus kepada Inspektorat Utama Badan Intelijen Negara yang turut membantu dalam penulisan artikel ini.

\section{Pendanaan}

Penulis tidak menerima bantuan pembiayaan untuk penelitian, kepenulisan (authorship), dan publikasi dari pihak manapun.

\section{Daftar Pustaka}

Bhakti, I. N., Mengko, D. M., Samego, I., Yanuarti, S., \& Siregar, S. N. (2016). Intelijen dalam Pusaran Demokrasi di Indonesia Pasca Orde Baru. Jurnal Penelitian Politik, 13(1), 69-82. https://doi. org/10.14203/jpp.v13i1.211

Born, H., \& Leigh, I. (2007). Mendorong Akuntabilitas Intelijen: Dasar Hukum dan Praktik Terbaik dari Pengawasan Intelijen (Terj.Ria Nuri Dharmawan). (B. S. Hadiwinata, Ed.). Jakarta: DCAFFES SSR Vol.I.

Djoyonegoro, N. (2018). Intelijen di Era Digital, Prospek dan Tantangan Membangun Ketahanan Nasional. Jakarta: CMB Press.

Drohan, W. H. (2010). Intelligence Oversight: Street Fight or Delicate Dance? American Intelligence Journal, 28(2), 83-86. Diunduh dari https://www.jstor.org/stable/44327163

Hillebrand, C. (2012). The Role of News Media in Intelligence Oversight. Intelligence and National Security, 27(5), 689-706. https://doi.org/10.1080/02684527.2012.708521

Inspektorat Utama. (2019). Ikhtisar Laporan Hasil Pengawasan Inspektorat Utama Badan Intelijen Negara Tahun 2018. Naskah tidak dipublikasikan.

Jackson Jr., W. H. (1990). Congressional oversight of intelligence: Search for a framework. Intelligence and National Security, 5(3), 113-147. https://doi.org/10.1080/02684529008432065

Jemadu, A. (Ed.). (2007). Praktek-praktek Intelijen dan Pengawasan Intelijen Demokratis - Pandangan Praktisi (Terj.Aviva Nababan). Jakarta: DCAF-FES SSR Vol.II.

Karalekas, A. (1983). Intelligence Oversight: Has Anything Changed? The Washington Quarterly, 6(3), 22-33. https://doi.org/10.1080/01636608309451517 
Keputusan Ketua Umum DPN AAIPI Nomor Kep-062/AAIPI/DPN/2018 tentang Kerangka Konseptual Pengawasan Intern Pemerintah Indonesia. (2018). Diunduh dari http://aaipi.or.id/ wp-content/uploads/2019/01/Kerangka-Konseptual-Pengawasan-AAIPI.pdf

Leigh, I. (2012). Rebalancing Rights and National Security: Reforming UK Intelligence Oversight a Decade after 9/11. Intelligence and National Security, 27(5), 722-738. https://doi.org/10.1080/0 2684527.2012.708525

Lurås, H. (2014). Democratic Oversight in Fragile States: The Case of Intelligence Reform in Bosnia and Herzegovina. Intelligence and National Security, 29(4), 600-618. https://doi.org/10.1080/02 684527.2014.915179

Obuobi, P. P. (2018). Evaluating Ghana’s Intelligence Oversight Regime. International Journal of Intelligence and CounterIntelligence, 31(2), 312-341. https://doi.org/10.1080/08850607.2017.13 75841

Peraturan DPR Nomor 2 Tahun 2014 tentang Tim Pengawasan Intelijen. (2014). Diunduh dari http:// berkas.dpr.go.id/jdih/document/peraturan_dpr/perdpr21_2014_2.pdf

Peraturan Pemerintah Republik Indonesia Nomor 60 Tahun 2008 tentang Sistem Pengendalian Intern Pemerintah. (2008). Diunduh dari http://www.bpkp.go.id/public/upload/unit/sakd/files/ PP60Tahun2008_SPIP.pdf

Peraturan Presiden Nomor 73 Tahun 2017 tentang Perubahan atas Peraturan Presiden Nomor 90 Tahun 2012 tentang Badan Intelijen Negara. (2017). Diunduh dari http://www.bin.go.id/asset/ upload/Perpres_Nomor_73_Tahun_2017.pdf

Peraturan Presiden Nomor 90 Tahun 2012 tentang Badan Intelijen Negara. (2012). Diunduh dari https://www.bphn.go.id/data/documents/12pr090.pdf

Pusat Pembinaan Profesi. (2018). Naskah Akademik Jabatan Fungsional Pengawas Intelijen. Naskah tidak dipublikasikan.

Puyvelde, D. Van. (2014). Intelligence, Democratic Accountability, and the Media in France. Democracy and Security, 10(3), 287-305. https://doi.org/10.1080/17419166.2014.946018

Samego, I. (2017). Politisasi Intelijen di Era Soekarno, 1945-1965. In I. N. Bhakti, D. M. Mengko, \& S. N. Siregar (Eds.), Intelijen dan Politik Era Soekarno. Jakarta: LIPI Press.

Undang-Undang Republik Indonesia Nomor 17 Tahun 2011 tentang Intelijen Negara. (2011). Diunduh dari http://www.bpkp.go.id/uu/filedownload/2/1/1923.bpkp

Wegge, N. (2017). Intelligence Oversight and the Security of the State. International Journal of Intelligence and CounterIntelligence, 30(4), 687-700. https://doi.org/10.1080/08850607.2017.1 337445

Widjajanto, A., \& Wardhani, A. (2008). Hubungan Intelijen-Negara 1945-2004. Jakarta: FES dan Pacivis.

Yanuarti, S. (2017a). Dinamika Pengawasan Intelijen di Indonesia. In I. N. Bhakti (Ed.), Intelijen dalam Pusaran Demokrasi di Indonesia Pasca Orde Baru. Jakarta: Penerbit Andi dan LIPI. 
Aparat Pengawas Intern Pemerintah: Perannya dalam Pengawasan Intelijen yang Akuntabel...

Yanuarti, S. (2017b). Pengawasan Intelijen Demokratik Sebagai Instrumen Pencegahan Pelanggaran HAM. Jurnal Penelitian Politik, 14(2), 127-147. https://doi.org/10.14203/jpp.v14i2.722

Zegart, A., \& Quinn, J. (2010). Congressional Intelligence Oversight: The Electoral Disconnection. Intelligence and National Security, 25(6), 744-766. https://doi.org/10.1080/02684527.2010.537871

\section{Tentang Penulis}

Wahyu Kuncoro adalah mahasiswa Program Studi Magister Kajian Intelijen Negara, Sekolah Tinggi Intelijen Negara, dengan ketertarikan pada studi pengawasan intelijen, operasi intelijen, dan strategi kontra intelijen. 